\title{
Competing Family Law Norms: Challenging Hong Kong Law's Conceptualization of the Ideal Family
}

\author{
Anne SCULLY-HILL* \\ The Chinese University of Hong Kong, \\ ascullybill@cubk.edu.hk
}

\begin{abstract}
Two recent Hong Kong cases have highlighted the developing dissonance between family law norms in Hong Kong and other jurisdictions. The first entailed a challenge to the Hong Kong Director of Immigration's refusal to recognize an overseas same-sex civil partnership as analogous to marriage. The second concerned a parental order for a child born overseas as a result of a surrogacy arrangement to an unmarried commissioning couple. These two cases challenged a specific conceptualization of the family in Hong Kong law: a preference for a heterosexual, married couple as the basis for the family unit. However, other common law jurisdictions would recognize the applicants' claims to family status, as do international human rights principles. This article explores the scope and intersection of Hong Kong's family law values, its private international law obligations, and the potential for invoking the public policy exception in these cases. In doing so, it tests the extent to which Hong Kong law's conceptualization of the "Ideal Family" can be legitimately imposed to oust the claims of the "Other Family" to legal recognition.
\end{abstract}

\section{CHALLENGES TO HONG KONG LAW'S CONCEPT OF THE "IDEAL FAMILY"}

Recently in Hong Kong, two cases have come before the courts which have highlighted the dissonance between Hong Kong's own domestic family law and that of other jurisdictions. These cases give rise to possible conflicts of laws issues and, more broadly, they open up debates on the potential for change to the shape and content of domestic family law norms.

In the first case, QT $v$ Director of Immigration, ${ }^{\mathrm{I}}$ Hong Kong's immigration authorities refused to confer dependant status on the same-sex civil partner of a woman who had been granted a visa to live and work in Hong Kong. The couple's civil

\footnotetext{
LL.B. (Hons) (Lond.), LL.M. (Lond.); Associate Professor, Faculty of Law, The Chinese University of Hong Kong. The author wishes to thank the anonymous reviewers for their helpful and constructive comments. Any errors of course remain the author's own.

I. QT $v$ Director of Immigration [2016] HKEC 587.
} 
partnership is legally recognized in England and Wales, their country of domicile, and they have complied fully with the necessary formalities of English law. Moreover, since 20I4, the law of their domicile allows their civil partnership to be converted into a same-sex marriage. ${ }^{2}$ The partner of the visa-holder applied for judicial review to challenge the Immigration Department's refusal to recognize her as a dependant of her visa-holding partner. The Court of First Instance held that the applicant was unsuccessful on the basis that the Director of Immigration has not discriminated against the applicant. The court held, amongst other reasons not directly relevant to this article, that a registered civil partnership between two women is not sufficiently analogous to a marriage to be recognized by Hong Kong law. ${ }^{3}$ The case is now open to appeal. It raises the question of whether the Court of First Instance's decision is correct when considered from the perspective of conflicts of laws obligations, in particular, the recognition of competing family law norms from other jurisdictions.

The second case, Re D (Parental Order: $s$ I2 Parent and Child Ordinance (Cap 429)), ${ }^{4}$ concerns a couple's application for a "parental order" in relation to their child. The child was born in America as a result of a commercial surrogacy arrangement at a time when the couple were unmarried. Whilst the arrangement was legal in America, both the unmarried status of the couple and the commercial nature of the arrangement made the surrogacy unlawful in Hong Kong. ${ }^{5}$ Consequently, the possibility of a statutory "parental order" being made by the Hong Kong courts in favour of the commissioning couple is rendered impossible, leaving the couple and the child in a state of legal limbo. In these proceedings, Hong Kong's Family Court, which sits at the level of District Court, heard an application to transfer the case up to the High Court, given the gravity and the unprecedented nature of the issues raised. The application to transfer was successful, but to date the case has not been listed to be heard.

The common thread joining the challenges raised in these cases is a specific conceptualization of the family in Hong Kong law. Members of the executive and the legislature have, on occasion, articulated a preference for conceptualizing the family unit as based on the marriage of a heterosexual couple. Such an articulation has been put forward either as their personal views, or as an observation of the preferences of Hong Kong society. ${ }^{6}$ For example, in 1998, when debating the introduction of

2. Marriage (Same Sex Couples) Act 2013 (UK), c $30, \mathrm{~s} 9$.

3. QT $v$ Director of Immigration, supra note I at [96].

4. $\operatorname{Re} D\left[20 \mathrm{I}_{5}\right]$ I HKLRD 229

5. $\quad$ See Parent and Child Ordinance (Cap 429) s I 2.

6. In relation to surrogacy see the Hong Kong Legislative Council's debate as to the parameters of legal recognition of surrogacy arrangements, see Legislative Council Secretariat, Report of the Bills Committee on Human Reproductive Technology Bill, CB(2) 2296/99-00 (I4 June 2000), online: Legco.gov.hk < http://www.legco.gov.hk/yr98-99/english/bc/bc53/report/b2296e.pdf> and Hong Kong Legislative Council, Official Record of Proceedings (22 June 2000), online: Legco.gov.hk < http://www.legco.gov. hk/yr99-oo/english/counmtg/hansard/ooo622fe.pdf > ; in relation to the Hong Kong Executive's negative response to a question raised in the Legislative Council as to the recognition of overseas same-sex marriages as valid marriages in Hong Kong, see Hong Kong Legislative Council, Press Release, "LCQ7: Provision of same-sex marriage registration services by foreign consulates" (Io December 20I4), online: Info.gov.hk < http://www.info.gov.hk/gia/general/2OI4I 2/IO/P2OI 4 I 20909 I 8.htm> . 
legislation regulating human reproductive technology in Hong Kong, the then Secretary for Health \& Welfare said:

[I]n order to minimize the ethical problems arising from surrogacy arrangements, we propose to prohibit commercial surrogacy ... Having taken into account the importance of a family to the upbringing of a child, we propose to limit generally the provision of reproductive technology services to persons who are married to each other. This is to allow children to be raised and taken care of by both father and mother. ${ }^{7}$

Similarly, in relation to the notion of recognizing same-sex relationships as "family relationships", a member of the Legislative Council noted - whilst debating a motion for a public consultation on legislation to address sexual orientation discrimination - that "Hong Kong is a Chinese society where the understanding of the composition of families and couples is the simple marriage between men and women". 8

That conceptualization of the family is now increasingly under attack. One of the strongest challenges lies in the claims by the applicants in the two cases above to the legitimacy of their own "family" status - a legitimacy based both in recognition conferred by other jurisdictions and as provided for by international human rights jurisprudence. For example, questions of conflicts of laws may arise for Hong Kong residents who marry or register same-sex partnerships with a person domiciled in a country where these relationships are recognized. Alternatively, as in QT, a conflict arises where same-sex partners domiciled in a jurisdiction which recognizes their relationship come to Hong Kong and find their status rejected. In terms of surrogacy, conflicts may arise where a couple domiciled in Hong Kong goes through a surrogacy process overseas, are recognized there as legitimate, but are not recognized as being eligible for the conferral of parental status in Hong Kong. Alternatively, where a couple domiciled overseas but resident in Hong Kong have a child overseas by surrogate, they may - upon returning to Hong Kong - be told that the child is not legally recognized as their child. This has significant, and negative, consequences for the purposes of the child receiving a "dependant" visa. Lastly, in relation to both same-sex marriage and surrogacies, individuals domiciled in Hong Kong may claim a conflict between Hong Kong's domestic law and the international law norms to which Hong Kong has committed itself. In essence, the question becomes: if other common law jurisdictions recognize the applicants' claims to family status, as do international human rights principles, why won't Hong Kong?

An attempt to answer this question will be made by seeking the sources of the legal dissonance evident in these cases, identifying the extent of the tensions between these competing legal norms, and exploring the extent to which Hong Kong can, in the changing global landscape of family law, maintain domestic

\footnotetext{
7. Hong Kong Legislative Council, Official Record of Proceedings (9 September I998), online: Legco.gov. hk < http://www.legco.gov.hk/yr98-99/english/counmtg/hansard/980909fe.htm> .

8. Hong Kong Legislative Council, Official Record of Proceedings (7 November 2012), online: Legco.gov. hk < http://www.legco.gov.hk/yr I 2-I3/english/counmtg/hansard/cmi I 07-translate-e.pdf> .
} 
conceptualizations of the family at odds with international and transnational family law concepts and trends.

\section{THE HONG KONG LAW ON MARRIAGE AND PARENTHOOD BY MEANS OF REPRODUCTIVE TECHNOLOGY}

\section{A. Marriage Hong Kong Style}

I. The background to the law on heterosexual, monogamous marriage

Since October I97I, the only legally recognized form of marriage in Hong Kong is marriage as defined under the Marriage Ordinance, which in turn is based on the English common law decision of Hyde $v$ Hyde. ${ }^{9}$ Previously there had been a variety of acceptable forms of marriage reflecting the different cultural values of different sections of the Hong Kong population. These included not only marriage under the Marriage Ordinance for non-Chinese since i 876 but also multiple forms of Chinese marriage for ethnically Chinese residents of Hong Kong, including the potentially or actually polygamous Chinese customary marriages. However, these Chinese forms of marriage were expressly outlawed by the Marriage Reform Ordinance, enacted in 1970, and the preference for the Hydev Hyde form of marriage was asserted. ${ }^{\text {IO }}$ The privileged status accorded to this monogamous, heterosexual form of marriage is given legislative form in s 40 of the Marriage Ordinance as follows:

(I) Every marriage under this Ordinance shall be a Christian marriage or the civil equivalent of a Christian marriage.

(2) The expression 'Christian marriage or the civil equivalent of a Christian marriage' implies a formal ceremony recognized by the law as involving the voluntary union for life of one man and one woman to the exclusion of all others.

Moreover, under s 20(I)(d) of the Matrimonial Causes Ordinance ${ }^{\mathrm{II}}$ enacted in $\mathrm{I} 972$, a marriage which is not between parties of the opposite sex is explicitly stated as being void. This latter section is materially identical to the English legislative provision in $\mathrm{I}$ (c) of the Nullity of Marriage Act I97I. That statutory provision was introduced into English law following the decision in Corbett $v$ Corbett (otherwise Ashley) ${ }^{\mathrm{I2}}$ that parties to a lawful marriage must be respectively male and female as designated at birth, based upon their biological characteristics. Hong Kong law's traditional insistence on marriage as a heterosexual union is demonstrated by an application for judicial review, W $v$ Registrar of Marriages, ${ }^{{ }^{3}}$ which challenged the constitutional validity of precisely the statutory provisions relating to gender. The case had to progress through the full hierarchy of the Hong Kong courts before the applicant was successful.

\footnotetext{
9. Hyde $v$ Hyde (I 866), LR I P\&D I30.

Io. Marriage Reform Ordinance (Cap I78); see also L $v$ T [2003] HKEC 27I at [39].

I I. Matrimonial Causes Ordinance (Cap I79).

I2. Corbett $v$ Corbett (otherwise Ashley) [197I] P 83.

I3. Wv Registrar of Marriages [2013] 3 HKLRD 90.
} 
2. The recent restatement of the heterosexual nature of marriage in Hong Kong The background to the W case began in 1997 when Hong Kong's "mini-constitution", the Basic Law, ${ }^{\mathrm{I} 4}$ negotiated by the United Kingdom and China prior to the handover of sovereignty from the former to the latter, came into force. The Basic Law protects Hong Kong residents' fundamental rights, including the right to marry. ${ }^{15}$ All provisions of domestic legislation must comply with the terms of the Basic Law. Those that do not may be declared invalid by the courts. Within this constitutional framework, W, a Hong Kong permanent resident, made an application for judicial review challenging the lawfulness of aspects of the Marriage Ordinance. ${ }^{\mathrm{I}}{ }^{6} \mathrm{~W}$ had been registered at birth as male, but was subsequently diagnosed with gender identity disorder. W then underwent psychiatric assessment and hormonal treatment and lived for a period of "real life experience" as a woman. W was subsequently given sex reassignment surgery in Hong Kong at hospitals managed by the Hospital Authority. ${ }^{17}$ The Hospital Authority then certified that the applicant's gender should now be recognized as female. Consequently, W's educational certificates, identity card, and passport were amended to show her new name and acquired gender. Subsequently, W sought confirmation from the Registrar of Marriages that she could now marry her boyfriend in her acquired female gender. In response, the Registrar determined that only heterosexual marriage was possible under s 40 of the Marriage Ordinance and gender for the purpose of marriage was by biological sex as designated at birth and recorded on the birth certificate. Any later medical intervention or other change to biological sex would not be taken into account.

The application for judicial review comprised two alternative submissions. First, the Registrar had misconstrued the meaning of "male" and "female" as used in the legislation. Second, if he had not so misconstrued those provisions, then s 40 and s 2 I of the Marriage Ordinance which replicates the English common law definition of marriage as given in Hyde $v$ Hyde, were unconstitutional in that they infringed W's right to marry under art 37 of the Basic Law and/or art I9(2) of the Hong Kong Bill of Rights. ${ }^{\text {I }}$

The applicant lost at first instance and in the Court of Appeal. However, on appeal to Hong Kong's highest court, the Court of Final Appeal, she won. The decision of the Court of Final Appeal turned on what constitutes gender identity for the purposes of marriage. The court held that the Corbett meaning of "woman" was based on biological aspects of gender identity only and thus too narrow. However, the court went to great lengths to state that:

It was no part of the appellant's case that same-sex marriage should be permitted. The contention advanced is that she is for legal purposes a woman and entitled to marry a person of the opposite sex. We should make it clear that nothing in this judgment is intended to address the question of same-sex marriage. ${ }^{\text {I9 }}$

\footnotetext{
I4. Basic Law of the Hong Kong Special Administrative Region of the People's Republic of China (adopted at the Third Session of the Seventh National People's Congress on 4 April I990).

I 5. Ibid, art 37. See also the Hong Kong Bill of Rights Ordinance (Cap 383), art I9.

I6. Marriage Ordinance (Cap I8I).

I7. W $v$ Registrar of Marriages, supra note I3 at [19].

I8. Ibid at [3].

I9. Ibid at [2].
} 
Instead, the Court of Final Appeal decided in favour of W, in part because unless her reassigned gender was legally recognized, the "very essence of the right to marry" 20 was violated. The restrictive statutory meaning of "man" and "woman" meant that the applicant, designated male at birth, was precluded from marrying a man. However, in her newly acquired female gender, and feeling herself to be a heterosexual woman, she wanted only to marry a man. Thus, to say that in her male "birth gender" she was free to marry a woman and therefore free to exercise her right to marry was, in her circumstances, meaningless.

The Court of Final Appeal's very careful delineation of the case as not raising issues pertaining to same-sex marriage is indicative of the resistance in Hong Kong to forms of marriage other than a heterosexual marriage. Further confirmation of this resistance can be seen - despite this clear judicial statement that on its facts the application in $W$ did not present any need to consider same-sex marriages - in the subsequent media coverage of the case. There were reports about anxieties that a finding in W's favour would sufficiently extend society's conception of marriage to open the door to the possibility of same-sex marriage in Hong Kong. ${ }^{2 \mathrm{I}}$ The strong reluctance on the part of the government to engage with the question of same-sex marriage was clearly apparent when, as a consequence of the $W$ decision, the Hong Kong administration introduced a Marriage Amendment Bill in the Legislative Council. This Bill was intended to implement the necessary changes arising from the court's finding of constitutional invalidity of s 40 of the Marriage Ordinance. In the accompanying briefing notes, the Hong Kong administration made clear that the possibility of opening up discussion on same-sex marriage was expressly curtailed and indeed stated explicitly that nothing in the legislative proposal would change the heterosexual nature of marriage in Hong Kong. ${ }^{22}$ Thus, the domestic family law norms in relation to marriage, as promoted by the Hong Kong government and presented in the domestic legislation, are firmly rooted in the concept of marriage as a heterosexual union.

\section{B. On Parenthood by Assisted Conception}

I. Parenthood where conception is by natural means: a focus on biology

Where a birth is the result of natural conception, Hong Kong's law on motherhood follows the English common law, declaring that motherhood is based on giving birth: "Mater semper certa est, pater incertus est". ${ }^{23}$ Such is the law's respect for the biological link between birth mother and child that even Chinese customary laws, which would usually be respected as having prior standing in terms of family status for

\footnotetext{
20. Ibid at [IO8]-[I I 2].

2I. See e.g. Niall FRASER, "Case that could drag HK out of dark ages on sex change”, South China Morning Post (8 August 20I0), online: South China Morning Post < http://www.scmp.com/article/721654/casecould-drag-hk-out-dark-ages-sex-change $>$ and Niall FRASER, "I want to marry my boyfriend, says woman who was a man", South China Morning Post (8 August 2010), online: South China Morning Post < http://www.scmp.com/article/721 572/i-want-marry-my-boyfriend-says-woman-who-was-man > .

22. Legislative Council Panel on Security, Follow up on the Court of Final Appeal order in the Judicial Review case W v Registrar of Marriages (FACV 4/20I2), CB(2) 588/I3-I4(O8) (7 January 20I4), online: Legco. gov.hk < http://www.legco.gov.hk/yri3-I4/english/panels/se/papers/seoIo7cb2-588-8-e.pdf> .

23. The Ampthill Peerage Case [1977] AC 547: she who gives birth is the mother.
} 
Chinese inhabitants of Hong Kong, will not override the biological connection between mother and child. For example, where a husband and wife divorce, whilst the wife's connection to her husband and his family is severed, the court has refused to accept that her connection to her children of that marriage is also severed. ${ }^{24}$ The Hong Kong law on fatherhood also followed the English common law presumptions, ${ }^{25}$ but is now given legislative form in s 5 of the Parent \& Child Ordinance, enacted in $1993 .{ }^{26}$ The legal recognition of fatherhood was, at the time of enactment of the Ordinance, extended so that a father may also be legally recognized as such both at the request of the mother (through a declaration by the mother and a statutory declaration by the father), as well as at the request of the "father" (through a declaration by him and statutory declaration by the mother). ${ }^{27}$

\section{The law on parenthood by assisted conception}

Where birth is the result of assisted conception, parenthood is regulated by both the Parent and Child Ordinance ${ }^{28}$ and the Human Reproductive Technology Ordinance. ${ }^{29}$ The latter was enacted in 2000 following a long process of consultation and debate. Under these intersecting legislative frameworks, the definition of parenthood is restrictive. It is restrictive, first, in the sense that the only people who can become legally recognized parents via some form of reproductive technology are married, infertile couples. ${ }^{30}$ Second, under s I4 of the Ordinance, where the reproductive technology is used in relation to a surrogate mother commissioned by a married couple, the procedure must use the gametes of at least one of the married couple:

[P]rohibition against using donated gametes in surrogacy arrangement:

Without prejudice to the operation of the Parent and Child Ordinance (Cap 429), no person shall, for the purposes of a surrogacy arrangement, use gametes other than the gametes of 2 persons who are-

24. Leung Lai Fong $v$ Ho Sin Ying [2009] I 2 HKCFAR 58 I.

25. A presumption arising from marriage: Banbury Peerage Case (I 8 I I) I Sim \& St I 53: the "pater est" rule; alternatively where an unmarried couple had agreed to enter both names on the birth certificate, this would lead to a presumption of paternity.

26. Parent and Child Ordinance, supra note 5, s 5: (I) A man shall be presumed to be the father of a child-(a) if he was married to the mother of the child at any time and if there arises by virtue of that marriage a presumption of law that the child is the legitimate child of that man; or $(b)$ where no man is presumed to be the father under paragraph (a), and subject to section Io(3), if he has been registered as the father of the child by an entry made after the commencement of this section in any register of births kept by the Registrar of Births and Deaths under any Ordinance.

27. Births and Deaths Registration Ordinance (Cap I74) s I 2.

28. Parent and Child Ordinance, supra note 5.

29. Human Reproductive Technology Ordinance (Cap 56I).

30. Ibid, Long Title: An Ordinance to regulate reproductive technology procedures, and the use, for research and other purposes, of embryos and gametes; to confine the provision of reproductive technology procedures to infertile couples subject to any express provision to the contrary in any code; to regulate surrogacy arrangements; to establish a Council on Human Reproductive Technology; and to provide for matters incidental thereto or connected therewith; see also s. I 5(5): " Subject to subsections (6), (7) and (8), no person shall provide a reproductive technology procedure to persons who are not the parties to a marriage.(6) Without prejudice to the operation of section I4, subsection (5) shall not apply in the case of a reproductive technology procedure provided to a person who is to be a surrogate mother where the procedure is provided pursuant to the surrogacy arrangement under which she is to be the surrogate mother." 
(a) the parties to a marriage; and

(b) the persons referred to in paragraph (a)(ii) of the definition of "surrogate mother" in so far as that arrangement is concerned. ${ }^{3 \mathrm{I}}$

The restrictive nature of the legislative framework for surrogacy arrangements outlined above is further limited by the provisions that surrogacy arrangements are unenforceable $\mathrm{e}^{32}$ and commercial surrogacy is prohibited. ${ }^{33}$

Motherhood is defined under s 9 of the Parent and Child Ordinance as gestational and thus in a surrogacy situation, the legally recognized mother will, if and until changed by court order, be the surrogate. Fatherhood via assisted conception, and this includes surrogacy, is defined in s ro of the Parent and Child Ordinance:

(I) This section applies in the case of a child who is being or has been carried by a woman as the result of the placing in her of an embryo or of sperm and eggs or her artificial insemination.

(2) If-

(a) at the time of the placing in her of the embryo or the sperm and eggs or her insemination, the woman was a party to a marriage; and

(b) the creation of the embryo carried by her was not brought about with the sperm of the other party to the marriage, then, subject to subsection (5), the other party to the marriage shall be regarded as the father of the child unless it is shown that he did not consent to the placing in her of the embryo or the sperm and eggs or to her insemination (as the case may be).

(3) If no man is regarded, by virtue of subsection (2), as the father of the child but-

(a) the woman and her male partner together obtained treatment services in the course of which the embryo or the sperm and eggs were placed in the woman or she was artificially inseminated; and

(b) the creation of the embryo carried by her was not brought about with the sperm of that man, then, subject to subsection (5), that man shall be regarded as the father of the child.

In surrogacy terms, this means that, if the surrogate is married, her husband will be the father of the surrogate child. If the surrogate mother is not married, then a man attending treatment with her would be the father; this could of course include the husband in the commissioning couple.

Given these statutory provisions, the commissioning couple, to be deemed legal parents of the child, must apply to court for a parental order under s I 2 of the Parent and Child Ordinance after the child is born. The conditions pertaining to the grant of a parental order under s $\mathbf{I}_{2}$ are also restrictive: there must be a biological link between the child born and at least one of the commissioning couple (either gametes of husband, wife, or both were used to create the embryo implanted into the surrogate); the application for the order must be made within six months after the birth; the child must be living with the husband and wife or either of them at the time of the application; the husband or wife or both must be domiciled in

\footnotetext{
3I. Ibid, $\mathrm{SI} 4$.

32. Ibid, si 8 .

33. Ibid, si7.
} 
Hong Kong, have habitual residence of one year in Hong Kong, or have a substantial connection to Hong Kong; the husband and wife at the time of making the order must be over I 8 years old; the legal father and mother of the child at birth must have given informed consent freely; no money has changed hands beyond reasonable expenses; and the court has jurisdiction whether the surrogate's pregnancy and the subsequent birth of the child took place in Hong Kong or not.

\section{The consequences of Hong Kong law's preference for heterosexual married parents} Taking into account the various statutory limitations on parenthood via assisted reproduction, it seems clear that the domestic legal norm for parenthood is grounded squarely within a heteronormative conservative tradition.

In Hong Kong, only one case on the application for a parental order arising from a surrogacy arrangement has thus far come before the courts. That case is $R e D$ (Parental Order: s I2 Parent and Child Ordinance (Cap 429)), which is outlined above in the introduction. ${ }^{34}$ As noted above, although the applicants in this case were given leave to transfer to the High Court, the case has not yet been listed. In the same-sex partnership case of $Q T$, when faced with a legal challenge, the Immigration Department offered, on "humanitarian" grounds only, a dependant visa to the applicant's partner. ${ }^{35}$ Whilst there is no evidence of a similarly exceptional offer in the $R e D$ case, one can ask whether a similar solution may have been offered. However, this is pure speculation as no information is available, other than the fact the case has not yet been listed.

Other reports of children born via surrogacies outside of the legislative conditions necessary for the award of a parental order are equally inconclusive. For example, the media has reported at least one high profile overseas surrogacy arrangement undertaken by an unmarried Hong Kong man, resulting in the birth of three sons. Following referral of the matter to the relevant authorities, the media reported: "The case is pending police investigation, said a government official, who noted that the law would apply to cases even in which payment is made outside of Hong Kong." ${ }^{6}$ The most recent reports available indicate that no action is known to have been taken: neither to confer Hong Kong status on the children as the legal children of the commissioning man despite his unmarried status and consequent breach of the conditions for a parental order under s I 2, nor to investigate whether an offence had been committed if the surrogacy arrangement was later found to be commercial in nature. ${ }^{37}$ There are of course evidential problems in bringing a prosecution for

34. Re D, supra note 4 .

35. Stuart LAU, "Lesbian challenges Hong Kong's decision to refuse her a dependant visa”, South China Morning Post (I 3 May 201 5), online: South China Morning Post < http://www.scmp.com/news/hongkong/law-crime/article/I 794647/lesbian-challenges-hong-kongs-decision-refuse-her-dependant > .

36. Cathy YAN, "Maternal Mystery: Babies Bring Joy, and Questions, in Hong Kong”, The Wall Street Journal (I4 December 20IO), online: The Wall Street Journal < http://www.wsj.com/articles/ SBI000I424052748703471904576002913040745224>.

37. "Peter Lee surrogacy case referred to police", South China Morning Post (2 December 20Io), online: South China Morning Post < http://www.scmp.com/article/732I7I/peter-lee-surrogacy-case-referredpolice $>$. 
extra-territorial conduct, ${ }^{38}$ but this does not change the fact that the reported behaviour gave rise to questions about the application of the law.

\section{The Legitimate Family in Hong Kong Law}

Looking at the law on marriage and the law on surrogacy arrangements, it is possible to conclude that, given the restrictions written into the relevant ordinances, the law enshrines a very specific conceptualization of "the legitimate family". This is a heterosexual married couple raising children with a biological connection to one or both parents. This rigid conceptualization has given rise to two forms of legal challenges. The first challenge emerges from those domiciled in jurisdictions with different conceptualizations of what constitutes a "legitimate" family and who seek similar recognition while in Hong Kong. The second comes from those domiciled in Hong Kong and who have sought to take advantage of the different family law norms established in overseas jurisdictions to shape their own family lives.

\section{PRIVATE INTERNATIONAL LAW AND FAMILY STATUS AS APPLIED IN HONG KONG}

When such legal challenges to Hong Kong law's conceptualization of the "ideal family" are raised in Hong Kong courts, the question becomes one of conflict of laws. Hong Kong has a well-established body of private international law jurisprudence. In some ways, therefore, these challenges do not present a problem for the Hong Kong legal system.

\section{A. In Relation to Marriage}

\section{The dual domicile rule}

The validity of marriage can be addressed in terms of essential validity and formal validity. In relation to essential validity, Hong Kong has followed the English law's traditional approach: capacity to marry is determined by each spouse's ante-nuptial domicile, ${ }^{39}$ so that where both spouses have capacity to marry under their ante-nuptial domicile, the marriage will be a valid marriage. This is the "dual domicile" rule. ${ }^{40}$ In Hong Kong, questions as to whether a "marriage" is an essentially valid marriage have arisen primarily in relation to foreign polygamous marriages or regarding Chinese customary marriages and unions of concubinage within Hong Kong. The decisions of

38. Ibid: "Democratic Party lawmaker James To Kun-sun, who is also a lawyer, said a police investigation was unlikely because evidence of irregularity would be too thin. "Just because someone is rich and can afford to hire a surrogate mother, it does not mean he would actually do it," he said. Nor would any participants be likely to admit to taking part, he added".

39. Suen Toi Lee v Yau Yee Ping [200I] HKCFA 2I; (200I) 4 HKCFAR 474: essential validity of the marriage depends on the capacity under the ante-nuptial domicile of the party. Per Millett NPJ, obiter: "The law of Hong Kong recognizes unions of concubinage validly entered into abroad just as it recognizes marriages validly entered into abroad."

40. Brook v Brook (I86I), 9 HLC I93, I I ER 703; Sottomayor v de Barros (I877), 3 PD I (UKCA) (Cf Sottomayor $v$ de Barros (No.2) (I879), 5 PD 94 (UKCA)). 
the courts in the polygamy cases have applied the ante-nuptial, dual domicile rule, with the result that if the parties' ante-nuptial domicile would view the marriage as valid, then Hong Kong law will treat the marriage as valid. ${ }^{4 \mathrm{I}}$ However, there may be further express statutory limitations on the power of the Hong Kong courts to make certain orders in relation to such a marriage. ${ }^{42}$

\section{QT $v$ Director of Immigration and the limits to the dual domicile rule}

The argument was made in QT that if polygamous marriages, which depart from the Hyde v Hyde formula of marriage as between "one man and one woman", could be legally recognized in Hong Kong on the basis of the dual domicile rule, then so should same-sex partnerships analogous to marriage. ${ }^{43}$ The Court of First Instance, however, declined to accept this argument. It stated that whilst the polygamous marriage itself may be accepted as a valid marriage, in relation to immigration decisions only one of the multiple wives could successfully apply for a dependant visa. The Court held fast to the legal norm of marriage as a monogamous heteronormative institution, stating that:

[I] $\mathrm{f}$ the sponsor in Hong Kong chooses only one of the wives as the principal wife, and it is only that principal wife who can be regarded as the spouse for the purpose of the Policy to apply for a dependant visa... can render it consistent with Hong Kong law on monogamous marriage since, insofar as Hong Kong is concerned, the sponsor working in Hong Kong can only have one wife as his spouse to apply for a dependant visa... However, it is impossible to adopt a practice that could render any acceptance of a partner in a same-sex marriage or civil partnership to be treated as being consistent with an opposite-sex partner under a heterosexual marriage. The sponsor in Hong Kong would have a "spouse" who is of the same-sex. ${ }^{44}$

In response, counsel argued that this was to "turn a blind eye" to the polygamous nature of the marriage itself and thereby tacitly condone a form of marriage which fell outside the monogamous norm established by the Hyde $v$ Hyde formula for marriage. ${ }^{45}$ This was not accepted by the court. However, was the court's approach right? Does it matter whether a polygamous marriage can be made "to look like" a monogamous marriage?

On a literal application of the "dual domicile" rule, a wide range of conceptions of marriage would have to be accepted for foreign domiciled married couples in Hong Kong. Hong Kong law does not stipulate the extent to which foreign marriages must fit the Hyde $v$ Hyde formula in order for them to be accepted as legally recognizable

4I. Graeme JOHNSTON, The Conflict of Laws in Hong Kong, 2d ed (Hong Kong: Sweet \& Maxwell, 20I 2) at $[7.088]$.

42. Matrimonial Causes Ordinance, supra note II, s 9: jurisdiction to grant various orders including a divorce decree is limited, inter alia, to monogamous marriages, and these are defined in $s 2$ of the Ordinance, if it took place outside Hong Kong, as celebrated or contracted in accordance with the law in force at the time and in the place where the marriage was performed and recognized by such law as involving the voluntary union for life of one man and one woman to the exclusion of all others (emphasis added).

43. QT $v$ Director of Immigration, supra note I at [85]-[89].

44. Ibid at [86]-[89].

45. Ibid at [86]. 
marriages, although it clearly does make these judgments. Therefore, how monogamous must a monogamous marriage be? How heterosexual must a heterosexual marriage be? If the post-gender reassignment applicant in $W$ had married a woman, albeit in her birth gender (i.e. male), the marriage would legally be a heterosexual one, but in the eyes of the public it would have looked very much like a same-sex marriage. If the Director of Immigration will accept a polygamous marriage as monogamous as long as only one wife is given the title of "spouse" on a visa, where is the line to be drawn?

As Graeme Johnston notes, "in future, given social and legal changes across the world, it seems likely that the important practical questions will mostly relate to samesex marriages and analogous relationships." ${ }^{46} \mathrm{He}$ goes on to say that "in so far as the relationship will not be recognized in that full sense, the further question arises as to whether recognition in some lesser sense may be given to the relationship by the Hong Kong court". ${ }^{47}$ At present, in same-sex partnership or marriage cases, for those whose ante-nuptial domicile is Hong Kong, it is clear that only a heterosexual marriage will be legally recognized. ${ }^{48}$ For those couples whose ante-nuptial domicile recognizes same-sex partnerships as marriages or analogous to marriage, the decision in QT $v$ Director of Immigration departs from the "dual domicile" rule and accepts the view of the Immigration Department that same-sex partnerships will not be deemed analogous to marriage. Consequently, it is now necessary to explore and interrogate further the validity of the court's decision allowing the domestic marriage norm to oust the private international law convention of recognition of marriage under the "dual domicile" rule.

\section{B. In Relation to Parenthood via Surrogacy}

I. Whether, and in relation to whom, private international law conventions are engaged The extra-territorial reach of the legislation relating to overseas surrogacy arrangements and the subsequent conferral of parental status on a commissioning couple might suggest that the private international law question is redundant and that Hong Kong law must always be the applicable law. However, under the Parent and Child Ordinance, those who are domiciled in Hong Kong, or have resided there for one year prior to the application, or have a substantial connection with Hong Kong may apply for a parental order. However, it is not clear whether the legal restrictions govern all those who are eligible to apply for a parental order or only those who are domiciled in Hong Kong. Furthermore, this approach looks only at the commissioning couple and fails to consider the position from the perspective of the child born to the surrogate. For the child, there are two possible options: the child has the surrogate's domicile or, as for babies born in the United States, the child has American citizenship. If the child's domicile respects the surrogacy arrangement, does that change how the Hong Kong law applies?

\footnotetext{
46. Johnston, supra note $4 \mathrm{I}$ at [7.083].

47. Ibid.

48. Bart RWEZAURA, “To Be or Not To Be: Recognition of Same-sex Partnerships in Hong Kong” (2004) 34(3) Hong Kong Law Journal 557 at 56I; see also Robin A WARREN, “Gay Marriage: Analyzing Legal Strategies for Reform in Hong Kong and the United States” (2004) I3(3) Pacific Rim Law \& Policy Journal $77 \mathrm{I}$ at $80 \mathrm{I}-802$.
} 
2. The consequences of extra-territorial provisions on legal recognition of parenthood via surrogacy

Turning to the practical consequences of the extra-territorial nature of Hong Kong's laws on surrogacy, a strict application of Hong Kong law does not take into account an important fact: a number of Hong Kong residents are nonetheless entering into surrogacy arrangements overseas. Some will do so as unmarried couples or individuals and for some, these arrangements may also be commercial in nature. Thus, Hong Kong residents are undertaking such surrogacy arrangements irrespective of Hong Kong law. ${ }^{49}$

Consequently, the children born and brought into Hong Kong are not deemed to be children of the commissioning adults. They potentially have no right of abode in Hong Kong, nor do they possess any of the rights and interests that flow therefrom. They are also not recognized as being related to the commissioning adults. This failure to engage with both the reality of parenthood via surrogacy and the possible solutions arising from private international law results in numerous detrimental practical consequences in terms of the would-be parents' ability to make decisions for their children, for example, consent to medical treatment.

There is also the question of international comity. Jurisdictions such as the state of California, for instance, make express provision for the conferral of parental status on commissioning couples who comply with certain criteria. ${ }^{\circ}$ The parental status is given prior to the birth of the child and registered on the birth certificate, and it is not simply a form of adoption. ${ }^{5}$ The rigidity of the Hong Kong legislation and the absolute dearth of case law in Hong Kong means that we have no way of knowing whether the courts would rely on Hong Kong law to oust the competing surrogacy law norms of the other relevant jurisdictions in order to maintain Hong Kong's own conception of the legitimate "ideal family".

\section{THE PUBLIC POLICY EXCEPTION}

In one respect, however, the foregoing discussion of the dual domicile rule and the conventions and comity of private international law may in fact be redundant. If Hong Kong truly wishes to maintain a highly traditional and restrictive vision of the legitimate "ideal family", it may avail itself of the "public policy exception" to the recognition of foreign "personal laws”. As Johnston notes:

In certain exceptional circumstances, the Hong Kong court will decline to apply ordinary conflict of law principles on the ground that the result of applying foreign law is, having

49. See "More liberal access to surrogacy warranted", South China Morning Post (3 I January 20I I), online: South China Morning Post < http:/www.scmp.com/article/737246/more-liberal-access-surrogacywarranted >: "However, controversy and cultural attitudes have not deterred an increasing number of Asians generally from turning to overseas agencies for help to conceive a child with a surrogate. Surrogacy Centre Hong Kong estimates that inquiries from Hong Kong have tripled in the past five years and that those from the mainland have quadrupled".

50. Steven H SNYDER \& Mary Patricia BYRN, "The Use of Prebirth Parentage Orders in Surrogacy Proceedings" (2005) 39 Family Law Quarterly 633 at 643-647.

5I. Ibid. 
regard to the nature of that law or its effect in the particular case, repugnant to notions of Hong Kong public policy. ${ }^{52}$

The important questions now become: (I) what is the effect of invoking the public policy exception; and (2) what constitutes a legitimate reliance on Hong Kong's "public policy" on marriage and legal parenthood?

The answer to the first question must be that the public policy exception works not against the foreign law per se, but against the application of the status conferred by the foreign law in the factual situation before the courts. Thus, it is possible for the domestic law to recognize a legal status for some limited purposes which it would not otherwise recognize ${ }^{53}$ whilst, for policy reasons, declining to recognize the status in its completeness.

As to the question of what constitutes a legitimate invocation of the public policy exception, one key element is the identification of the scope and content of the relevant policy. It has been noted by commentators that whilst the public policy exception is necessary in the field of conflict of laws, "[n]o attempt to define the limits of that reservation has ever succeeded. All that can be done therefore is to enumerate the cases in which the recognition of enforcement of rights arising under foreign laws has been refused on this ground." 54 Thus, in some senses, one might say that it is up to the courts to decide what constitutes public policy.

This potentially provides the courts with very broad discretion, and it is perhaps something about which both judiciary and populace would feel a degree of unease. Indeed, as Mills observes, "critics point out that when the courts do decide to apply public policy it is not always easy to identify in advance what the content of public policy actually is." ${ }^{55}$ However, as Enonchong notes, the exclusion of foreign laws "on the grounds of public policy is of course a matter best left for the judge to decide at the time of the trial and in the light of the then prevalent values of the community." ${ }^{6} 6$ Building on Enonchong's reference to the judicial decisions made in relation to public policy based on the "then prevalent values of the community", we might usefully turn to Joost Blom's own interpretation of the proper meaning of "public policy" as one of the ways in which we can think about what might constitute a legitimate invocation of "public policy" to exclude foreign laws. For Blom, the policy invoked must be the current public policy, that is, "it must be today's moral and social values that are the touchstone for what is or is not acceptable." 57 This is perhaps particularly apt for the Hong Kong context where the Basic Law - Hong Kong's mini-constitution - has been

\footnotetext{
52. Johnston, supra note $4 \mathrm{I}$ at [4.034].

53. Ibid at [7.088] and [7.IOI]; see also Lord COLLINS et al, eds, Dicey, Morris \& Collins on the Conflict of Laws, I 5 th ed (London, UK: Sweet \& Maxwell, 20I6) at [5-005]-[5-007]; see also Joost BLOM, "Public Policy in Private International Law and Its Evolution in Time” (2003) 50(3) Netherlands International Law Review 373 at 382-383.

54. Dicey, Morris \& Collins, supra note 53 at [5.008].

55. Alex MILLS, "The Dimensions of Public Policy in Private International Law" (2008) 4(2) Journal of Private International Law 201 at 202.

56. Nelson ENONCHONG, "Public Policy in the Conflict of Laws: A Chinese Wall around Little England?" (I996) 45(3) International and Comparative Law Quarterly 633 at 636.

57. Blom, supra note 53 at 383 .
} 
affirmed by the local judiciary as being a living document developing over time to reflect the changing values of Hong Kong. ${ }^{5}$

This raises a third question: How do we identify the content of "current public policy"? Adopting Blom's analysis, leaving aside the usual exceptions of penal, revenue, other public laws, and laws of immediate application, there are four categories of interests which inform public policy: the national interest of the domestic jurisdiction; the values inherent in the domestic private legal institutions; domestic values related to inter-jurisdictional considerations; and values from international legal sources. ${ }^{59}$ For our purposes, the values inherent in the domestic private legal institutions and the values from international legal sources have greatest resonance, and these will now be considered to identify Hong Kong's “public policies” relating to same-sex marriage, or analogous relationships, and parenthood by surrogacy.

\section{WHAT IS HONG KONG'S CURRENT PUBLIC POLICY ON MARRIAGE AND ON PARENTHOOD BY MEANS OF REPRODUCTIVE TECHNOLOGY?}

\section{A. Identifying Hong Kong's Public Policy in Relation to Same-Sex Marriage \\ I. The Hong Kong establishment's perception of values inherent in the domestic jurisdiction regarding marriage}

Following Blom's analysis as one way to identify public policy, the first step is to articulate the values inherent in the domestic jurisdiction. The Hong Kong government's view is that same-sex marriages would violate the accepted societal norms and values of Hong Kong. This view manifested itself in the Hong Kong administration's briefing document following the Court of Final Appeal's decisions in the $W$ case, ${ }^{60}$ which confirmed that marriage in Hong Kong would remain heterosexual. The connection between values and policy was also identified in $W$ by the Hong Kong courts. As Marsh and Ramsden note:

[I]n W, both the Court of First Instance (CFI) and Court of Appeal found that marriage was to be defined in accordance with "societal consensus". Cheung J for the CFI noted that marriage, as a social institution, "is necessarily informed by the societal consensus and understanding regarding marriage and the essence thereof in that society". ${ }^{61}$

A further expression of the Hong Kong establishment's values in relation to marriage came with the introduction of same-sex marriage in English law. The Hong Kong

58. Ng Ka Ling and another $v$ The Director of Immigration (I999) 2 HKCFAR 4 at 28 ; see also The Honourable Mr Justice BOKHARY, gen ed, Michael RAMSDEN \& Stuart HARGREAVES, eds, Hong Kong Basic Law Handbook (Hong Kong: Sweet \& Maxwell, 201 5 ) at [39.4.2].

59. Blom, supra note 53 at 385-397.

60. See above Follow up on the Court of Final Appeal order in the Judicial Review case W v Registrar of Marriages, supra note 22.

6I. Michael RAMSDEN \& Luke MARSH, "Same-sex marriage in Hong Kong: the case for a constitutional right” (2015) I9(I) The International Journal of Human Rights 90 at 93. 
government raised an objection to the solemnization of same-sex marriages at the British Consulate in Hong Kong. ${ }^{62}$ In response to a question in the Legislative Council, the Secretary for Mainland and Constitutional Affairs said: "Same-sex marriage or civil partnership not contracted in compliance with the requirements under Hong Kong law will have no legal effect in Hong Kong, i.e. will not be legally recognized as valid marriage in Hong Kong." ${ }^{6} 3$

\section{Challenging the establishment's perception?}

Commenting on Hong Kong's anti-gay culture, Chan has said that:

[T]he anti-gay rights culture in Hong Kong, as alleged, consists essentially of the primacy of Confucianism aligned with Christianity. Each of them, standing on its own, provides its own rationalizations-not to be confused with reasons-as to why homosexuality and sexual minority rights in Hong Kong are wrong... The government then embraces this alleged culture as mainstream consensus within the populace in order to stonewall the development and protection of sexual minorities' rights. ${ }^{64}$

Chan deconstructs the "Chinese values" and "Christian values" arguments against the acceptance of same-sex relationships, saying that they are not an accurate representation of the values claimed and that in fact, the way they are represented is only a partial view of the cultural discourse on same-sex relationships. In other words, this perspective is a snapshot represented as a totality. ${ }^{65}$ Since Chan's article was written, two empirical surveys have sought to identify the current domestic values in relation to the acceptance or otherwise of same-sex relationships in Hong Kong. In the first, Loper, Lau, and Lau noted that "government authorities claim that same-sex marriage is highly controversial and point to an apparent lack of public approval for legalizing same-sex marriage." 66 Their research found that whilst there was no majority support for the legalization of same-sex marriage, a large majority of people in Hong Kong support conferring rights on committed same-sex couples. ${ }^{67}$ Later that year, the Family Council released the findings of its own survey which showed that the majority surveyed did not accept same-sex relationships but there was greater acceptance amongst the younger respondents. Thus, it seems that in terms of reflecting Hong Kong's contemporary values, two trends can be discerned: a nuanced response toward the extension of same-sex rights coupled with a generational shift.

62. Christy CHOI, "UK consulate in Hong Kong bars same-sex weddings after government objection", South China Morning Post (9 June 20I4), online: South China Morning Post < http://www.scmp.com/ news/hong-kong/article/I $52823 \mathrm{I} /$ uk-diplomatic-missions-allow-same-sex-marriages-not-hong-kong $>$.

63. Press Release, Provision of same-sex marriage registration services by foreign consulates, supra note 6.

64. Phil CW CHAN, "Stonewalling through Schizophrenia: An Anti-Gay Rights Culture in Hong Kong?" (2008) I 2(2) Sexuality \& Culture 7 I at 75-76.

65. Ibid at 83 .

66. K A LOPER, Holning LAU \& Charles LAU, "Research Shows a Majority of People in Hong Kong Support Gay and Lesbian Couples' Rights, Not Necessarily Marriage" (Briefing Paper, Centre for Comparative and Public Law, University of Hong Kong) (University of Hong Kong Faculty of Law Research Paper No 20I4/OOI) (3 January 20I4), online: < http://papers.ssrn.com/sol3/papers.cfm? abstract_id=2374875>.

67. Ibid. 
Moreover, the shift towards greater acceptance of same-sex rights is not confined to the public. Two recent legislative innovations suggest that the Hong Kong government and law-makers are more willing to recognize and protect those in same-sex relationships. ${ }^{68}$ First, in 2009, legislation on legal injunctions to protect those subject to domestic violence was extended to apply to same-sex partners under the Domestic and Cohabitation Relationships Violence Ordinance (Cap I89). The second innovation concerns the Electronic Health Record Sharing System Ordinance (Cap 625), which defines who can be a "substitute decision-maker" for non-competent patients. In the original Bill, the "substitute decision-maker" was defined as "immediate family members" and related to the patient by blood, marriage, adoption, or affinity. However, some legislators successfully argued that a person cohabiting with the patient should also be included. Thus, in the enacted Ordinance, a "substitute decision-maker" is now defined to also include "a person residing with the health-care recipient", and this may well include same-sex partners.

Whilst the government may be able to reference conservative social values as a justification for invoking the public policy exception to the recognition of same-sex marriage, this is not a comprehensive representation of the values of the Hong Kong public. It is therefore arguably not a "legitimate" representation of the norms shaping the "ideal family" in Hong Kong.

\section{Values from international legal sources}

The next step in identifying Hong Kong's public policy, following Blom's analysis, is to consider values from international legal sources. Hong Kong has incorporated, almost in its entirety, the International Covenant on Civil and Political Rights (ICCPR) into Hong Kong law via the Hong Kong Bill of Rights Ordinance (Cap 383) (BORO). The Covenant is further protected in Hong Kong law through Article 39 of the Basic Law. Article I9 of BORO incorporates Article 23 of the ICCPR, stating that the "right of men and women of marriageable age to marry and to found a family shall be recognized". Moreover, Article 37 of the Basic Law "guarantees that the freedom of marriage of Hong Kong residents and their right to raise a family freely shall be protected by law". More broadly, Article 25 of the Basic Law provides that all Hong Kong residents will be equal before the law while Article 22 of the BORO states:

[A]ll persons are equal before the law and are entitled without any discrimination to the equal protection of the law. In this respect, the law shall prohibit any discrimination and guarantee to all persons equal and effective protection against discrimination on any ground such as race, colour, sex, language, religion, political or other opinion, national or social origin, property, birth or other status.

The decision in Leung $v$ Secretary for Justice confirmed that the word "sex" in Article 22 encompasses "sexual orientation" 69 and therefore, equality of treatment is

68. Domestic and Cohabitation Relationships Violence Ordinance (Cap I 89): for a history of the legislative reform see Anne SCULLY-HILL, "Domestic Violence in Hong Kong” in Phillippa HEWITT, ed, Family Law and Practice in Hong Kong, 2d ed (Hong Kong: Sweet \& Maxwell, 20I4) 48I.

69. Leung $v$ Secretary for Justice [2005] HKEC I334 at [43]-[46]; see also Secretary for Justice v Yau Yuk Lung Zigo (Yau Yuk Lung) [2007] 3 HKLRD 903; (2007) Io HKCFAR 335. 
expected. Ramsden and Marsh have since made the argument - distinguishing the UN Human Rights Committee's restrictive interpretations of the ICCPR's Article 23 right to marry in Joslin v New Zealand - that Article 37 of the Basic Law, unlike Article 23 of the ICCPR, is gender neutral and further that:

[I]t is possible to fashion a right for same-sex couples to marry from Article 23, on the basis that this provision does not require 'men and women' to marry 'each other' as such. Further, it is arguable that the protected status of 'sex' in the anti-discrimination provision of Article 26 also includes sex discrimination: a harmonious reading of Article 23 and Article 26 may thus justify the right to same-sex marriage. ${ }^{70}$

\section{Lawful restrictions on the right to marry?}

It has been said that the right to marry may be lawfully restricted in order to achieve a rational and legitimate purpose. It has also been argued by some that marriage as a heterosexual union, in conformity with the Hyde definition, forms the basis for stable families living in a stable society. Opponents of same sex marriage advocate that it is therefore acceptable to restrict the right to marry to heterosexuals in order to pursue a rational and legitimate aim of social stability. ${ }^{71}$ However, the validity of this view has been rejected by the courts. In the $W$ case, the Court of Final Appeal found that although societal consensus may be a justification for extending the scope of a right, "[r]eliance on the absence of a majority consensus as a reason for rejecting a minority's claim is inimical in principle to fundamental rights". ${ }^{72}$ Similarly, the Court of Appeal in Leung $v$ Secretary for Justice observed that the "[c]ourt must ... be acutely aware of its role which is to protect minorities from the excesses of the majority". ${ }^{73}$ The court in QT $v$ Director of Immigration seems to accept this, albeit obliquely, by distinguishing the facts of $Q T$ from precedent cases in which the purported aim of restricting applicants' rights was to promote a traditional form of family life:

[I]n assessing whether the "discrimination" was fair ... the respondents advanced the submissions that it was so because the interpretation was made with the aim to protect traditionally recognized family life ... This was rejected by the court to be a good reason to satisfy the proportionality test to show that the discrimination was fair...(4) This is clearly different and distinguishable from the present case where, as I explained above, the aim and proper context advanced by the Director are to strike the right balance between maintaining the tight immigration control in Hong Kong and attracting skilled foreigners to come to work in Hong Kong. The Director does not rely on an aim to protect traditional family life to justify the difference in treatment. (5) As such, [the precedent case] cannot be treated as an authority that runs against the Director's submissions that, given the aim and context of striking a right balance between immigration control and attracting skilled foreigners to work in Hong Kong, the difference between married and unmarried persons justifies the difference in treatment under the Policy. ${ }^{74}$

\footnotetext{
70. Ramsden \& Marsh, supra note 6I at 92.

7I. Ibid at 97 .

72. Wv Registrar of Marriages, supra note I3.

73. Leung $v$ Secretary for Justice [2006] 4 HKLRD 2 I I.

74. QT $v$ Director of Immigration, supra note I at [55].
} 
The court maintained that immigration policy, in contrast to a policy to promote a majority view of what constitutes a "proper family", is a rational and legitimate reason to restrict the categories of persons who are eligible for a dependant's visa. Further, restriction of immigration based on "the bright line" of married or unmarried status is justifiable because immigration control must be based on what can be lawfully achieved. However, the connection between tight immigration control and the use of the married/unmarried distinction arguably is not rational. The court stated that:

[P]roperly understood, the rational connection is between adopting a bright line rule based on marital status to achieve the Legitimate Aim which can be applied lawfully in Hong Kong. In immigration context, the lawfully valid way in Hong Kong to give an incentive to attract certain skilled foreigners to come to work in Hong Kong is to, among others, allow him or her to bring the spouse who is married to him or her as lawfully recognized in Hong Kong (i.e., under a heterosexual and monogamous marriage). ${ }^{75}$

This does not address the very core meaning of the visa being sought: a dependant's visa. Surely, the appropriate cut-off point to achieve the legitimate, rational aim of immigration control should not be whether someone is married to the sponsor or not. Rather, it is whether there is a true relationship of dependence, understood within a context of permanency, between the sponsor and the alleged dependant, including intimate partners, children, elderly parents and siblings. In terms of a rational connection between immigration restrictions and immigration control, the dependant visa is not given only because of a marriage certificate but because the parties concerned are dependent upon one another for any combination of a range of needs: financial, emotional, psychological, care-giving. These factors may be present in a marital relationship but are not confined to marriage.

As to the argument that immigration policy can only be based on what is "lawfully" possible, dependence between cohabiting same-sex partners can be recognized without condoning "unlawful" behaviour. Homosexual conduct was decriminalized in Hong Kong in I994, and since the decisions in Leung ${ }^{76}$ and Yau, ${ }^{77}$ differential treatment of homosexual and heterosexual sexual activity in the criminal law has been declared unconstitutional. Thus, contrary to the court's reasoning, the "lawful" attainment of the legitimate aim of immigration control is not undermined by moving from reliance on production by an applicant of their marriage certificate to the requirement of evidence of dependence. Arguably, the court's reliance on "lawful marriage" as the shaping factor for a "bright line" distinction in terms of eligibility for a dependant's visa is a distraction rather than a rational connection between tight immigration control and the need to attract talented foreigners to Hong Kong. Thus, it is argued here that the court's finding on this issue is not adequately convincing and does not provide a firm foundation for the claim, even in the context of immigration control, to a public policy exception to Hong Kong's private international law commitments.

\footnotetext{
75. Ibid at [93].

76. Leung $v$ Secretary for Justice, supra note 73.

77. Secretary for Justice $v$ Yau Yuk Lung Zigo, supra note 69.
} 


\section{The "current" public policy on same-sex marriage in Hong Kong}

By combining Blom's categories of the interests of the domestic jurisdiction and values derived from human rights norms already adopted in Hong Kong, it seems that there are potential representations of Hong Kong's current public policy on same-sex marriage which differ from that claimed by the Hong Kong government. Indeed, the fact that the government's stance is based on conceptions of marriage that are drawn from English legislation imposed by a predominantly English Executive during English rule is further cause for thought. Can the outdated legislation on which the government relies, and from which England has since departed, truly be said to reflect the values and wishes of Hong Kong people?

Given the analysis above, the implication for public policy formation in Hong Kong is that if Hong Kong does not actually embrace the validity of same-sex marriage, then it should at least prevent discrimination by recognizing the relationships of dependence between same-sex spouses and partners. Where the courts are called upon to determine claims to legal recognition of those relationships, they should do so in a way that acknowledges the requirements of the universal human rights norms to which Hong Kong is committed and the shifting and nuanced local population's values as to marriage and same-sex relationships.

Where overseas family law norms are in competition with domestic law norms, the courts should not simply reiterate the "lawful" status of heterosexual marriage in Hong Kong and the factually different legal status of unmarried and married couples in Hong Kong. Rather, they should engage with the conflict of laws points presented to it. Where argument is submitted to the court that the laws and public policy of Hong Kong do not recognize the family law norm claimed by the foreign domiciliaries, then the court should confirm the disparity between the foreign law and Hong Kong law and interrogate the government's definition of "public policy" with a view to determining its legitimacy. Consequently, should the claimed public policy not be legitimate, as in current and accurate, the court should apply the principle of comity and respect the personal laws of those foreign domiciliaries. Under such an analytical framework, it is submitted that the court should have ousted the domestic law's conceptualization of the "ideal family" and awarded the applicant in QT a dependant's visa.

\section{B. In Relation to Parenthood via Surrogacy}

Turning now to the thorny issue of Hong Kong's public policy exception to recognition of parenthood via certain types of surrogacy arrangements, the same framework analysis shall be applied.

I. Competing perceptions of the values inherent in the domestic jurisdiction regarding parenthood via surrogacy

First, in relation to Blom's category of "values inherent in the legal institutions of the domestic jurisdiction", values similar to those invoked to oppose same-sex marriage have been articulated. In presenting the Human Reproductive Technology Bill for the Legislature's consideration in I998, the Hong Kong administration proposed that "RT [reproductive technology] procedures should be restricted to legally married couples, 
having taken into account the majority of public views that welfare of children could be best protected when they are brought up by married couples." ${ }^{78}$ More recent media reports suggest that these traditional views persist:

[T]here's still a general belief in society that the traditional family ... is the best place to raise a baby...the convening council would be reluctant to loosen these requirements involving marital status, because there are a lot of different viewpoints from different groups of people on this issue. For example, creating a child without a father is a real concern to this society, he says. Hon Leung says this law should reflect what the majority of the community wants and "so far the majority of the community seems happy with the status quo". ${ }^{79}$

One particular attitude seems to be that reform of the law on surrogacy would weaken the institution of marriage. ${ }^{8 \circ}$ However, converse attitudes are slowly beginning to be expressed:

[T] he Ordinance is stuck at societal norms and the technology of decades ago. We're much more open-minded [now], we're less conservative as single parent families are more prevalent and so are same-sex relationships. Even our Adoption Ordinance is more openminded now as it allows single parent adoption. ${ }^{81}$

Perhaps the most convincing evidence of a shift in attitude is demonstrated by the number of Hong Kong couples who actively pursue surrogacy as a means of achieving parenthood:

$[\mathrm{H}]$ ong Kong remains conservative on social issues. Advances in human reproductive technology, including greater acceptance of surrogacy, have put this ethos to the test. The law reinforces it by imposing tight controls. But it reckons without the lengths to which infertile couples are prepared to go to get a child, not to mention parenting by singles and same-sex couples. Their numbers are rising. ${ }^{82}$

Overseas clinics report Hong Kong people seeking surrogacy arrangements in jurisdictions as diverse as the United States, Thailand, and Taiwan where laws are not so restrictive. ${ }^{83}$ Therefore, it would seem that there is a growing divergence of attitudes to surrogacy amongst Hong Kong residents.

\section{Values from international legal sources}

We now consider Blom's subsequent category of values in the articulation of public policy, i.e. the values manifested in human rights norms. Hong Kong is a signatory to

78. Health and Welfare Bureau, The Administration's reply to the eight submissions to LegCo Bills Committee on the Human Reproductive Technology Bill, CB(2) 660/98-99(OI) (November I998), online: Legco.gov.hk < http://www.legco.gov.hk/yr98-99/english/bc/bc53/papers/p66oeor.pdf> .

79. Nan-Hie IN, "Hong Kong ban on IVF for unwed is discriminatory, say critics", South China Morning Post (9 January 2015), online: South China Morning Post < http://www.scmp.com/lifestyle/health/ article/I 677954/hong-kong-ban-ivf-unwed-discriminatory-say-critics $>$.

8०. Ibid: “...letting non-married individuals access assisted reproductive technology would weaken the institution of marriage."

8I. Ibid.

82. "More liberal access to surrogacy wanted", supra note 49.

83. "Hong Kongers unafraid to break law to realise dreams of parenthood", Global Health and Travel (February - March 20I 5), online: Global Health and Travel < https://www.fertility-miracles.com/PDFs/ Global_Health_and_Travel_Feb-March_20I 5.pdf > . 
the United Nations Convention on the Rights of the Child (UNCRC). Under the UNCRC, one of the key principles regarding the upbringing of children is the "best interests" principle. ${ }^{84}$ Research shows that it is generally in the best interests of the child to have an ongoing relationship with both parents, even after parental separation. ${ }^{85}$ This is therefore independent of the marital status of the parents and dependent instead on the quality of interaction between child and parent and between parents. By extension, being a "suitable" parent cannot be determined by marital status alone. Thus, granting parental status to commissioning parties to a surrogacy arrangement should be guided by the best interests of the child, rather than the relatively superficial categorization of suitability by reference to marital status. By failing to put the child's best interests as the primary consideration in any parental order application, the legislation is arguably in breach of the UNCRC.

A further challenge to the legitimacy of Hong Kong's stance on surrogacy lies in the practical consequences following the restrictions on parental orders following surrogacy. For example, the child's relationship with one or both commissioning parents may not be recognized in Hong Kong; the child will not be entitled to share right of abode with her parents; and if the child has a passport from the country of birth, the child will be forced to re-enter Hong Kong every few months on a tourist visa. The alternative is not to travel out of Hong Kong, which may result in illegal overstaying, and more significantly, not to be registered for public health and education services. Arguably, the legal framework which produces this situation is in breach of several UNCRC provisions, namely, articles 7 (registration, name, nationality, care), 8 (preservation of identity), and 9 (separation from parents). ${ }^{86}$

84. United Nations Convention on the Rights of the Child, 20 November I 989, I 577 UNTS 3 , online: United Nations Treaty Collection <http://untreaty.un.org >, art 3(I): In all actions concerning children, whether undertaken by public or private social welfare institutions, courts of law, administrative authorities or legislative bodies, the best interests of the child shall be a primary consideration.

85. Belinda FEHLBERG et al, "Caring for children after parental separation: would legislation for shared parenting time help children?” (Family Policy Briefing 7, University of Oxford Department of Social Policy and Intervention, May 20I I), online: Nuffield Foundation < http:/www.nuffieldfoundation.org/ sites/default/files/files/Would \% 2olegislation $\%$ 2 ofor $\%$ 2oshared $\%$ 2oparenting $\%$ 2otime $\%$ 2 ohelp $\%$ 2ochildren) OXLAP\% 20FPB\% 207.pdf > .

86. UNCRC, supra note 84 , arts 7-9 provides:Art 7:I. The child shall be registered immediately after birth and shall have the right from birth to a name, the right to acquire a nationality and, as far as possible, the right to know and be cared for by his or her parents.2. States Parties shall ensure the implementation of these rights in accordance with their national law and their obligations under the relevant international instruments in this field, in particular where the child would otherwise be stateless.Art 8: I. States Parties undertake to respect the right of the child to preserve his or her identity, including nationality, name and family relations as recognized by law without unlawful interference.2. Where a child is illegally deprived of some or all of the elements of his or her identity, States Parties shall provide appropriate assistance and protection, with a view to re-establishing speedily his or her identity.Art 9:I. States Parties shall ensure that a child shall not be separated from his or her parents against their will, except when competent authorities subject to judicial review determine, in accordance with applicable law and procedures, that such separation is necessary for the best interests of the child. Such determination may be necessary in a particular case such as one involving abuse or neglect of the child by the parents, or one where the parents are living separately and a decision must be made as to the child's place of residence.2. In any proceedings pursuant to paragraph I of the present article, all interested parties shall be given an opportunity to participate in the proceedings and make their views known.3. States Parties shall respect the right of the child who is separated from one or both parents to maintain personal relations and direct contact with both parents on a regular basis, except if it is contrary to the child's best interests.4. Where such separation results from any action initiated by a State Party, such as the detention, imprisonment, exile, deportation or death (including death arising from any cause while the person is in the custody of the 
In addition to the values manifested in the UNCRC, Hong Kong is also committed to upholding the value of non-discrimination. Article I of BORO provides that men and women should have "equal right to enjoyment of all civil political rights set forth in this Bill of Rights" and that the rights recognized therein "shall be enjoyed without distinction of any kind, such as race, colour ... and other status". The right to found a family is protected under Article I9 of BORO and therefore must be enjoyed free from discrimination. As such, the restriction of lawful surrogacy arrangements to married couples may be in breach of Article I. Unfortunately, the legislation has not yet been challenged in court.

\section{The "current" public policy on parenthood via surrogacy in Hong Kong}

Taking into account both the interests of the domestic jurisdiction and the values from human rights norms, a true representation of Hong Kong's current public policy on parenthood via surrogacy should reflect the transitioning nature of public values and the government's obligation to honour its commitments under the UNCRC and the BORO. The public policy as claimed by the government and as applied by the Immigration Department in $R e D$ is therefore not a legitimate invocation of public policy. Consequently, it is doubtful whether the government can properly avail itself of the public policy exception with regard to recognition of parenthood acquired by means of foreign declaration following a surrogacy arrangement.

\section{CONCLUSION}

Hong Kong's laws on marriage and parenthood differ from other jurisdictions. When conflicts between those laws arise, Hong Kong has sometimes declined to conform to the private international law convention of recognition of personal laws based on domicile. Instead, Hong Kong has relied on the public policy exception to oust foreign family law norms and privilege its own domestic norms. The extent to which this exception is available to Hong Kong, and consequently, the extent to which Hong Kong law can maintain its own conception of the "ideal family", depends on the extent to which the public policy position claimed by the Hong Kong government is legitimate. This legitimacy, in turn, hinges upon whether the government's public policy position is accurate, current, and inclusive of international human rights obligations as well as domestic values. Having considered the content of the relevant laws, the policy reasons for their enactment, the current values surrounding marriage and parenthood in Hong Kong and the human rights norms adopted by Hong Kong, the version of public policy being promoted by the Immigration Department cannot be said to be legitimate and, therefore, cannot justifiably oust the claims made by the applicants in QT $v$ Director of Immigration and Re D (Parental Order).

State) of one or both parents or of the child, that State Party shall, upon request, provide the parents, the child or, if appropriate, another member of the family with the essential information concerning the whereabouts of the absent member(s) of the family unless the provision of the information would be detrimental to the well-being of the child. States Parties shall further ensure that the submission of such a request shall of itself entail no adverse consequences for the person(s) concerned. 